\title{
Pregnancy Outcome in Maternal Crigler-Najjar Syndrome Type II: A Case Report and Systematic Review of the Literature
}

\author{
V. Passuello ${ }^{a} \quad$ A.G. Puhla ${ }^{a}$ S. Wirth ${ }^{c} \quad$ E. Steiner ${ }^{d} \quad$ C. Skala ${ }^{a} \quad$ H. Koelbl ${ }^{a}$ \\ N. Kohlschmidt ${ }^{\text {b, e }}$ \\ ${ }^{a}$ Department of Obstetrics and Gynaecology, ${ }^{b}$ Institute of Human Genetics, Johannes Gutenberg University of \\ Mainz, Mainz, 'Department of Paediatrics, HELIOS Klinikum Wuppertal, Witten/Herdecke University, Wuppertal, \\ ${ }^{\mathrm{d}}$ Department of Obstetrics and Gynaecology, GPR Klinikum Rüsselsheim, Rüsselsheim, and ${ }^{\mathrm{e}}$ Institute of Clinical \\ Genetics, Bonn, Germany
}

\section{Key Words}

Crigler-Najjar syndrome $\cdot$ Phenobarbital · Bilirubin $\cdot$ Uridine 5'-diphosphate-glucuronosyltransferase $\cdot$ UGT1A1 gene

\begin{abstract}
Objective: To report a case of maternal Crigler-Najjar syndrome (CNS) type II in pregnancy, systematically review the literature for similar case reports, and to evaluate whether pregnancy is safe in patients with the disease. Data sources included the PubMed and uptodate databases. Results: A 37-year-old mother with CNS type II was treated with phenobarbital during her pregnancy and her bilirubin levels were monitored. Her newborn had mild direct hyperbilirubinemia, did not require any treatment and his postnatal followup showed normal growth and development as well as normal hearing. Conclusion: CNS type II is rare, and only a few pregnancies with this condition have been reported. Maternal treatment with phenobarbital lowers the unconjugated bilirubin and avoids fetal and newborn sequelae.
\end{abstract}

Copyright $\odot 2009$ S. Karger AG, Base

\section{KARGER}

Fax +41613061234 E-Mail karger@karger.ch www.karger.com (c) 2009 S. Karger AG, Basel

$1015-3837 / 09 / 0263-0121 \$ 26.00 / 0$

Accessible online at:

www.karger.com/fdt

\section{Introduction}

Crigler-Najjar syndrome (CNS) is a rare autosomal recessive condition caused by complete (type I) or incomplete deficiency (type II) of hepatic microsomal bilirubin uridine 5'-diphosphate-glucuronosyltransferase(UDPGT) activity. It is characterized by congenital unconjugated hyperbilirubinemia $[1,2]$. The severe (type I) condition was reported initially by Crigler and Najjar in 1952 [3] and results in severe unconjugated hyperbilirubinemia and thus neurologic impairment (kernicterus). Type II, first described by Arias in 1962 [4], causes milder unconjugated hyperbilirubinemia and responds to phenobarbital treatment $[5,6]$. The gene coding for UDPG-T, UGT1A1, has been mapped to $2 \mathrm{q} 37$ and mutations associated with both type I and type II have been reported [7-9]. Maternal CNS type II is a rare situation and little is known about the effects of the condition on the mother and her fetus/newborn. We report a case with maternal CNS type II, the pregnancy management and the favorable outcome associated with this condition, and give a short overview of the literature about similar cases. 
Fig. 1. Maternal serum bilirubin levels and phenobarbital dosage throughout pregnancy.
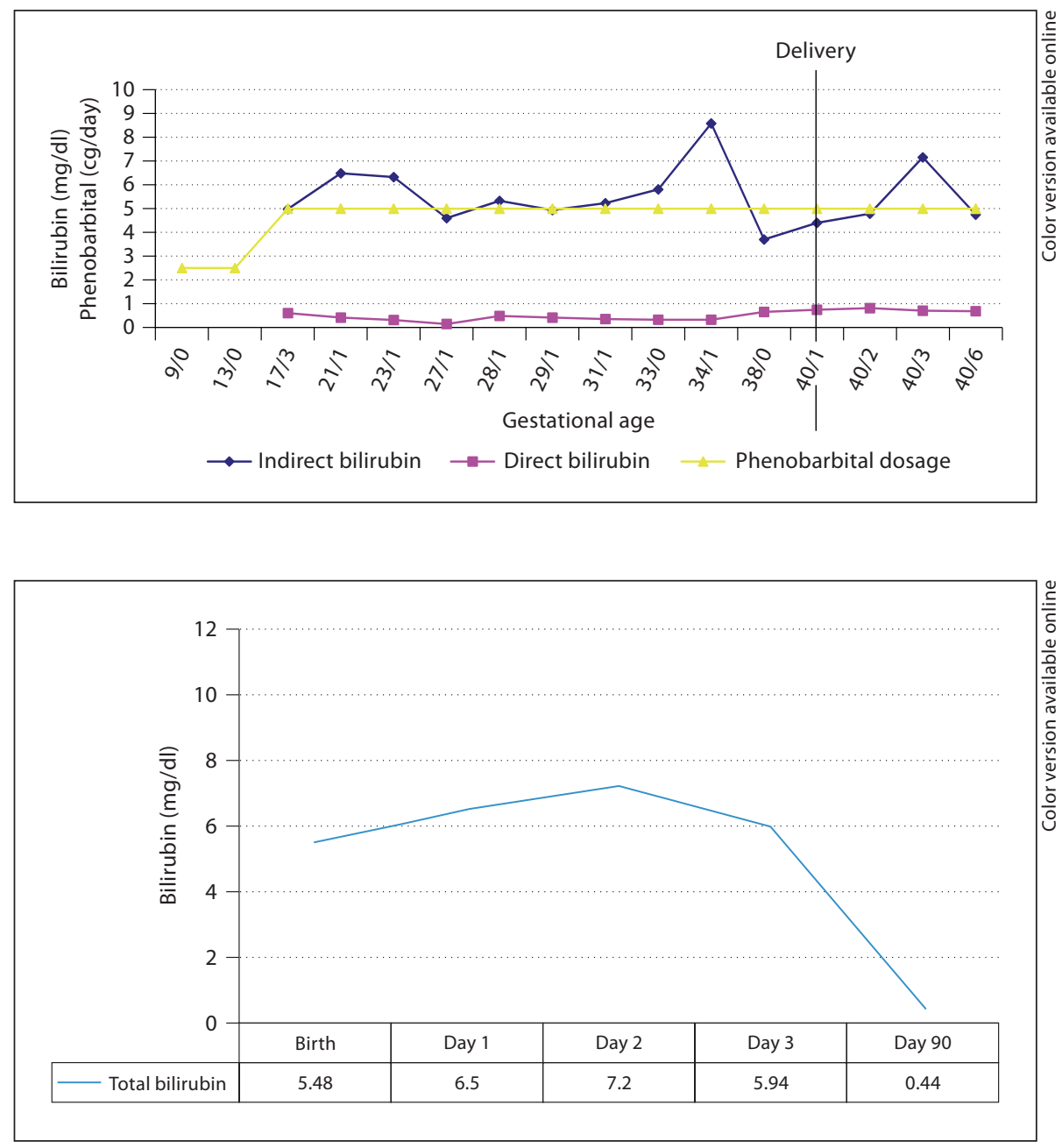

Fig. 2. Newborn's serum bilirubin levels.

\section{Methods}

We first searched the PubMed database for case reports of CNS in pregnancy (key words: Crigler-Najjar syndrome and/in pregnancy). For background information about CNS we used both the PubMed and the uptodate database (keywords: CriglerNajjar syndrome and review). After comparing the reported options of treatment of CNS in pregnancy, we specifically searched for evaluations of (1) phenobarbital treatment in pregnancy (key words: phenobarbital and pregnancy), and (2) hyperbilirubinemia and neonatal outcomes (key words: prenatal exposure, neonatal outcome, bilirubin, hyperbilirubinemia).

\section{Case Report}

The patient was a 37-year-old primigravida woman of Russian-German descent and her husband was 42 years old and of German descent. The couple was not consanguineous and their family histories were noncontributory. Specifically, there was no history of congenital abnormalities, mental retardation, neonatal/infant death, hepatic disease, jaundice, or neurological disorders in their families. The patient was referred to the Department for Ultrasound and Prenatal Medicine at 34/6 weeks of gestation for sonographic evaluation. She had jaundice and was diagnosed with CNS type II a few years ago based on past medical history of mild icterus which started in childhood, occasional fatigue and pruritus as well as investigations which showed unconjugated hyperbilirubinemia, normal liver enzymes and negative anti-HAV, anti-HBc and anti-HCV antibody titers. Antinuclear antibodies, antimitochondrial antibodies including anti-M2 and anti-M4, smooth muscle antibodies and antibodies to liver/kidney microsomes were also negative ruling out an autoimmune condition. Abdominal ultrasound showed no abnormalities, and thus a decision was made not to perform liver biopsy. She had been treated with phenobarbital $100-150 \mathrm{mg} /$ day for 9 years prior to her pregnancy and this resulted in a decrease in bilirubin levels (typical for CNS type II). Apart from that she was healthy, had no neurological abnormalities and had a university degree. Her pregnancy was initially uncomplicated. Her obstetrician decided to decrease her phenobarbital dosage to $25 \mathrm{mg}$ /day to reduce the risk of teratogenicity. Her bilirubin level was stable at around $4-6 \mathrm{mg} / \mathrm{dl}$ and never went above $9 \mathrm{mg} / \mathrm{dl}$ (fig. 1). 
Fig. 3. Transcutaneous bilirubin levels in a normal newborn population of $>35$ weeks' gestation [12]. SD = Standard deviation.

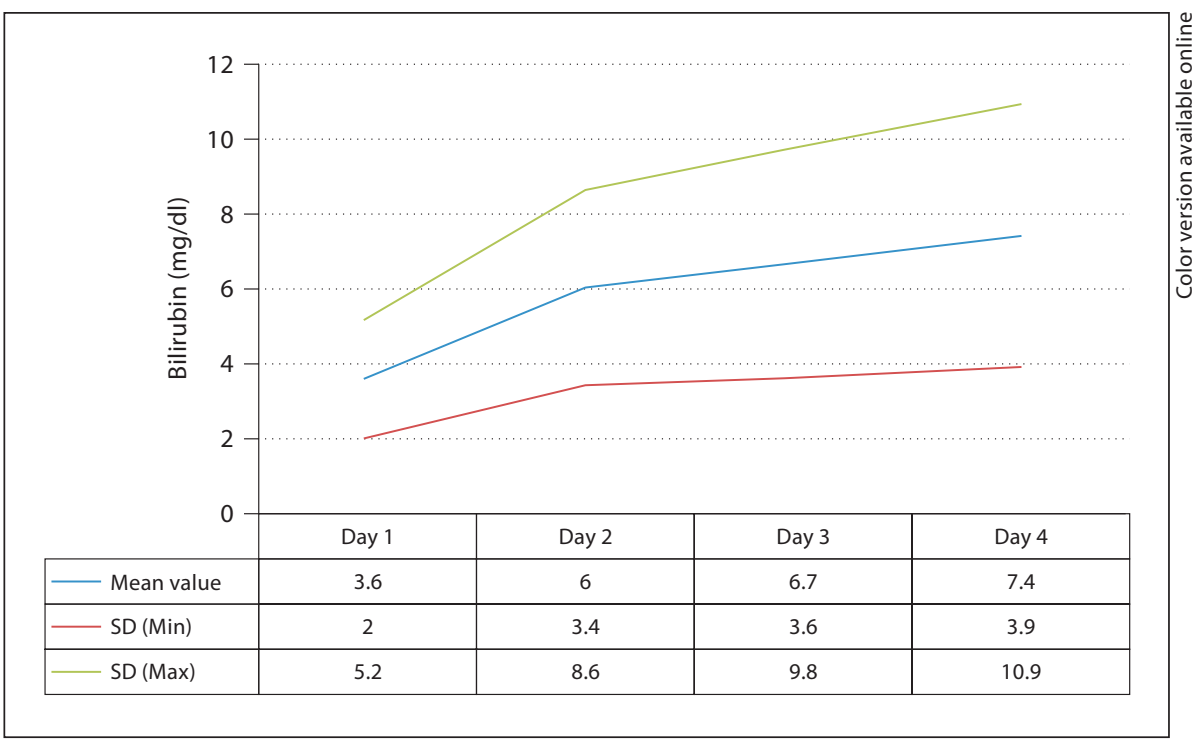

DNA analysis of the UGT1A1 gene showed that the patient is a compound heterozygote for the IVS1 + $5 \mathrm{G}>\mathrm{T}(\mathrm{c} .864+5)$ and c.C1175T mutations. Additionally, she was found to carry the A(TA) ${ }_{6}$ TAA/A(TA) 7 TAA polymorphism (known to be associated with Gilbert syndrome [10]). The couple was counseled regarding the husband's very low chance of being a carrier and a decision was made not to have DNA analysis of the UGT1A1 gene.

The pregnancy was initially uncomplicated. First trimester screening showed normal nuchal translucency $(1.6 \mathrm{~mm})$ and her adjusted risk for having a baby with Down syndrome was $1 / 1,289$. Detailed fetal ultrasound done at 19/6 weeks gestation and repeated during the 3 rd trimester of pregnancy showed no detectable fetal abnormalities. The couple declined amniocentesis [11].

Gestational diabetes was noted at 34 weeks gestation and was treated with insulin. Oxytocin stress test was done at 38 weeks gestation and was normal. The patient developed increasing pruritus and thus labor was induced at 40.1 weeks gestation. Delivery was spontaneous, vaginal and uncomplicated at 40.2 weeks' gestation and resulted in a healthy newborn girl. Her birthweight was 3,100 $\mathrm{g}$ (10th percentile) and her Apgar scores were 9, 10 and 10 at 1, 5 and $10 \mathrm{~min}$, respectively; the umbilical cord arterial blood $\mathrm{pH}$ was 7.37. The maternal and newborn bilirubin levels were monitored (fig. 1,2) and the final newborn bilirubin level measured upon discharge was $0.44 \mathrm{mg} / \mathrm{dl}$. Figure 3 shows the normal distribution of bilirubin levels in newborn children [12].

No abnormalities were detected on the newborn's physical examination apart from a nonsuspicious cardiac murmur. Hearing studies as well as brainstem auditory evoked potential performed at 1 month of age were normal. The baby was followed during her 1 st year of life and had normal growth and development. DNA analysis of the UGT1A1 gene done on the newborn showed that she inherited the c.C1175T but not the $\mathrm{A}(\mathrm{TA})_{7} \mathrm{TAA}$ variant, from her mother.

\section{Systematic Review of Case Reports}

To date, CNS in pregnancy has been reported only four times in CNS type II mothers (one with two pregnancies; table 1) [14-17] and twice in a CNS type I mother $[13,18]$.

In 2 cases [13, 17], the maternal condition was unknown during pregnancy, so there was no monitoring or therapy until upon delivery. In the other 4 cases, treatment with phenobarbital/phototherapy in CNS type I vs. phototherapy and albumin infusions in CNS type II was performed. Delivery was spontaneous, vaginal, in 2 cases, and by cesarean section in 3 cases; we have no information of two deliveries.

Pregnancy in CNS patients is a therapeutic challenge because of the risk of fetal kernicterus and rising bilirubin levels of the mother, who is exposed to the stress of pregnancy. Maternal-derived unconjugated bilirubin crosses the placental barrier by passive diffusion, so the fetus is at risk for bilirubin-induced neuronal degeneration leading to permanent neurologic impairment such as plegia, ataxia, deafness, spasticity, mental retardation, choreoathetosis, seizures, or death [19]. These complications have been described in a case of untreated hyperbilirubinemia in a pregnant CNS type I patient [13], leading to quadriplegia of the neonate. In all other reported cases, the neonates had a good outcome without treatment [14-16] or required only phototherapy [18]; one case required blood transfusion along with phenobarbital and phototherapy [17]. 
Table 1. Literature review of CNS in pregnancy

\begin{tabular}{|c|c|c|c|c|c|}
\hline Author, year & Disease type & $\begin{array}{l}\text { Maternal serum } \\
\text { bilirubin, } \mathrm{mg} / \mathrm{dl}\end{array}$ & $\begin{array}{l}\text { Maternal } \\
\text { treatment }\end{array}$ & Delivery & Newborn treatment/outcome \\
\hline $\begin{array}{l}\text { Taylor et al., } \\
1991 \text { [13] }\end{array}$ & CNS type I & $17-21.8$ & none & caesarean section & $\begin{array}{l}\text { phototherapy/quadriplegic } \\
\text { at } 18 \text { months }\end{array}$ \\
\hline $\begin{array}{l}\text { Smith et al., } \\
1994 \text { [14] }\end{array}$ & CNS type II & $5.3-9.6$ & none & $\begin{array}{l}\text { spontaneous, vaginal, } \\
\text { at term }\end{array}$ & no treatment required/normal \\
\hline $\begin{array}{l}\text { Ito et al., } \\
2001[15]\end{array}$ & $\begin{array}{l}\text { CNS type II } \\
\text { ( } 2 \text { pregnancies })\end{array}$ & NA & $\begin{array}{l}\text { phototherapy, } \\
\text { phenobarbital }\end{array}$ & NA & normal \\
\hline $\begin{array}{l}\text { Holstein et al., } \\
2005 \text { [16] }\end{array}$ & CNS type II & $4.2-8.9$ & $\begin{array}{l}\text { phototherapy, } \\
\text { phenobarbital }\end{array}$ & $\begin{array}{l}\text { primary caesarean } \\
\text { section }\end{array}$ & no treatment required/normal \\
\hline $\begin{array}{l}\text { Pinkee et al., } \\
2005 \text { [17] }\end{array}$ & CNS type II & $\begin{array}{l}10.8 \\
\text { (at delivery) }\end{array}$ & none & $\begin{array}{l}\text { spontaneous, vaginal, } \\
\text { at term }\end{array}$ & $\begin{array}{l}\text { blood transfusion, photo- } \\
\text { therapy, phenobarbital/ } \\
\text { normal }\end{array}$ \\
\hline $\begin{array}{l}\text { Gajdos et al., } \\
2006[18]\end{array}$ & CNS type I & $13.5-23.5$ & $\begin{array}{l}\text { phototherapy, } \\
\text { albumin infusions }\end{array}$ & caesarean section & phototherapy/normal \\
\hline
\end{tabular}

$\mathrm{NA}=$ Not available to the authors.

\section{Discussion}

Regarding the evaluation of whether pregnancy is safe in patients with CNS, we can say that the good outcome noted in our patient and her newborn should act as a positive message for other cases affected with this rare condition, preconditioning close monitoring of the maternal bilirubin serum levels.

To support our statement, we will substantiate it by means of some background information. CNS is a rare autosomal recessive disorder of bilirubin metabolism. Type I CNS is associated with severe jaundice and permanent neurologic damage (kernicterus). Type II CNS is associated with a lower serum bilirubin concentration and responds to phenobarbital treatment. Incidence of CNS is probably less than 1 case per 1,000,000 births. Only a few hundred cases have been described in literature, including 6 cases of CNS in pregnancy (table 1), and the exact prevalence is unknown.

CNS is caused by mutations of the bilirubin-uridineglucuronosyltransferase (UGT1A1) gene, resulting in either a complete absence of UGT (CNS type I) or a decreased enzymatic activity of UGT (CNS type II). To date, more than 70 mutations have been found (Human Gene Mutation Database at the Medical Genetics Institute in Cardiff). Genetic lesions in any of the five exons constituting the bilirubin UGT mRNA can abolish (CNS type I) or reduce (CNS type II) bilirubin-UGT activity.
In the case of CNS type I, the genetic lesions may result in a premature stop codon or a single amino acid substitution. The sequence abnormalities can be located in the region encoding the signal peptide or other domains of the enzyme, or even in the introns at the splice donor or splice acceptor sites. CNS type II is caused by point mutations that result in substitution of a single amino acid $[20,21]$.

Molecular analysis of the UGT1A1 gene of the patient revealed two different mutations which have not been reported previously. One allele was found to be changed at c. $864+5($ IVS1 +5$)$ with a guanine to adenine change. The other allele was mutated at c.1175 (C1175T). Both mutations are compound heterozygous and have not been listed in databases but seem to be causative for the enzymatic defect in the patient. Additionally, an $\mathrm{A}(\mathrm{TA})_{7} \mathrm{TAA}$ variant was detected. This variant is frequently observed in Gilbert-Meulengracht syndrome $[10,22]$ and might further impair the enzymatic activity.

Despite the severity of the disease, there are options for treatment of CNS [23-25] which include:

- Phototherapy: acts by converting a portion of bilirubin in a hydrophilic isomer, which can be excreted in the bile without the need for further conjugation in the liver. This technique involves exposure to light and heat $10-12 \mathrm{~h}$ per day [26].

- Phenobarbital: inducts the residual UGT1A1 activity present in CNS type II patients. 
- Liver transplantation: an efficacious therapy but the number of donor organs is limited and it requires lifelong immune suppression [27].

- Plasma exchange transfusion: acts by removing the bilirubin-saturated albumin and provides free albumin, which draws bilirubin from the tissues.

- Advances in gene therapy: introduction of a normal UGT1A1 gene has the potential for curing the defect leading to CNS [28]. Gene and cell transfer techniques are largely experimental at present, though animal experiments (Gunn rats) have been encouraging [29].

Of these, only phenobarbital treatment, phototherapy and albumin infusions have been reported in pregnancy with good neonatal outcomes [15, 16, 18].

There are several reports regarding placental bilirubin metabolism. To date, observations in animal studies and case reports of pregnant women with conjugated hyperbilirubinemia show that conjugated bilirubin does not cross the placenta from the maternal to the fetal circulation [30-32]. These findings contrast markedly with animal studies and observations of mothers with unconjugated hyperbilirubinemia, where the plasma concentrations of bilirubin are roughly the same between newborn and mother [18, 19, 31-33]. This suggests a placental barrier for conjugated bilirubin. In contrast, passive diffusion seems to be the predominant mechanism for the bidirectional placental flux of unconjugated bilirubin, although some authors report active transport in in vitro studies $[34,35]$. This means that maternal unconjugated hyperbilirubinemia (as in CNS) is of concern, whereas direct hyperbilirubinemia is not $[19,30]$.

Therefore, efforts in pregnant CNS patients should go towards keeping the maternal bilirubin at a stable/low level; in our case, this has been achieved with phenobarbital treatment. We were aware of the controversial findings regarding the teratogenic risk in phenobarbital treatment [36], but all studies refer to therapy of epileptic women in pregnancy who frequently take more than one drug. An increased risk for major congenital malformations has been reported by some authors [37-39], though a recent case-time-control study [40] found only borderline or no statistically significant associations between congenital abnormalities and antiepileptic drugs. Although some authors found negative effects (e.g. facial dysmorphisms, developmental retardation) of phenobarbital on the newborns of mothers who had taken doses of 750-1,500 mg/day for anticonvulsive treatment during pregnancy [41, 42], others saw little or no negative effects [43]. Our patient did not stop her phenobarbital medication during embryogenesis [in contrast to 15,16 ]. Nonetheless, looking at the case reports of pregnant CNS mothers, including our case, and the good outcome of the newborns [except in 13], it seems that phenobarbital is a safe option (with a maximum of $60 \mathrm{mg} /$ day reported).

Regarding the highest accepted level of unconjugated bilirubin in pregnancy, it is to say that it is unclear at which exact bilirubin level kernicterus will develop. Any studies so far referred to neonates but the objective of intrauterine tolerance to bilirubin has not been addressed yet. On the other hand, it is well-known that premature and sick neonates are more susceptible to hyperbilirubinemia than mature neonates $[44,45]$. We therefore monitored bilirubin levels closely, accepting levels of not more than $10 \mathrm{mg} / \mathrm{dl}$, because no case of kernicterus has been reported within these margins.

In conclusion, summarizing up the reports in world literature, we can postulate that (1) pregnancy in CNS patients is still a rare event; (2) maternal bilirubin serum levels should be kept below 8-10 mg/dl; (3) in CNS type II pregnant patients, phenobarbital treatment seems to be a safe option, and (4) neurologic follow-up including sensitive hearing tests of these children is strongly recommended, as hearing disorders are among the commonest sequelae of kernicterus $[46,47]$ and, though well treatable, are frequently underdiagnosed.

\section{References}

1 Chowdhury N, Chowdhury J: Crigler-Najjar syndrome. www.uptodate.com.

2 Roy KP, Othman M, Pigazzi A: Crigler-Najjar syndrome. www.emedicine.com.

3 Crigler JF Jr, Najjar VA: Congenital familial nonhemolytic jaundice with kernicterus; a new clinical entity. AMA Am J Dis Child 1952;83:259-260.

-4 Arias M: Chronic unconjugated hyperbilirubinemia without overt signs of hemolysis in adolescents and adults. J Clin Invest (NY) 1962;41:2233-2245.
5 Gupta R, Parashar Y: Crigler-Najjar syndrome type II. Indian J Pediatr 2004;71: 1043.

6 Trotman BW, Shaw L, Roy-Chowdhury J, Malet PF, Rosato EF: Effect of phenobarbital on serum and biliary parameters in a patient with Crigler-Najjar syndrome, type II and acquired cholestasis. Dig Dis Sci 1983;28: 753-762. 
7 Costa E: Hematologically important mutations: bilirubin UDP-glucuronosyltransferase gene mutations in Gilbert and CriglerNajjar syndromes. Blood Cells Mol Dis 2006; 36:77-80

-8 Seppen J, Bosma PJ, Goldhoorn BG, Bakker CT, Chowdhury JR, Chowdhury NR, Jansen PL, Oude Elferink RP: Discrimination between Crigler-Najjar type I and II by expression of mutant bilirubin uridine diphosphate-glucuronosyltransferase. J Clin Invest 1994;94:2385-2391.

-9 Ritter JK, Yeatman MT, Ferreira P, Owens IS: Identification of a genetic alteration in the code for bilirubin UDP-glucuronosyltransferase in the UGT1 gene complex of a Crigler-Najjar type I patient. J Clin Invest 1992; 90:150-155.

-10 Bosma PJ, Chowdhury JR, Bakker C, Gantla S, de Boer A, Oostra BA, Lindhout D, Tytgat GN, Jansen PL, Oude Elferink RP, et al: The genetic basis of the reduced expression of bilirubin UDP-glucuronosyltransferase 1 in Gilbert's syndrome. N Engl J Med 1995;333: 1171-1175.

-11 Francoual J, Trioche P, Mokrani C, Seboui H, Khrouf N, Chalas J, Clement M, Capel L, Tachdjian G, Labrune P: Prenatal diagnosis of Crigler-Najjar syndrome type I by singlestrand conformation polymorphism (SSCP). Prenat Diagn 2002;22:914-916.

-12 Maisels MJ, Kring E: Transcutaneous bilirubin levels in the first 96 hours in a normal newborn population of $>$ or $=35$ weeks' gestation. Pediatrics 2006;117:1169-1173.

$\checkmark 13$ Taylor WG, Walkinshaw SA, Farquharson RG, Fisken RA, Gilmore IT: Pregnancy in Crigler-Najjar syndrome. Case report. Br J Obstet Gynaecol 1991;98:1290-1291.

-14 Smith JF, Baker JM: Crigler-Najjar disease in pregnancy. Obstet Gynecol 1994;84:670672.

15 Ito T, Katagiri C, Ikeno S, Takahashi H, Nagata N, Terakawa N: Phenobarbital following phototherapy for Crigler-Najjar syndrome type II with good fetal outcome: a case report. J Obstet Gynaecol Res 2001;27:33-35.

-16 Holstein A, Plaschke A, Lohse P, Egberts EH: Successful photo- and phenobarbital therapy during pregnancy in a woman with Crigler-Najjar syndrome type II. Scand J Gastroenterol 2005;40:1124-1126.

17 Pinkee S, Renu A, Bharati M: Crigler-Najjar syndrome with pregnancy. J Obstet Gynecol India 2005;55:270-271.

18 Gajdos V, Petit F, Trioche P, Mollet-Boudjemline A, Chaveaud A, Myara A, Trivin F, Francoual J, Labrune P: Successful pregnancy in a Crigler-Najjar type I patient treated by phototherapy and semimonthly albumin infusions. Gastroenterology 2006;131:921924.

19 Lipsitz PJ, Flaxman LM, Tartow LR, Malek BK: Maternal hyperbilirubinemia and the newborn. Am J Dis Child 1973;126:525527.
-20 Kadakol A, Ghosh SS, Sappal BS, Sharma G, Chowdhury JR, Chowdhury NR: Genetic lesions of bilirubin uridine-diphosphoglucuronateglucuronosyltransferase(UGT1A1) causing Crigler-Najjar and Gilbert syndromes: correlation of genotype to phenotype. Hum Mutat 2000;16:297-306.

21 Maruo Y, Verma IC, Matsui K, Takahashi H, Mimura Y, Ota Y, Mori A, Saxena R, Sato $\mathrm{H}$, Takeuchi Y: Conformational change of UGT1A1 by a novel missense mutation (p.L131P) causing Crigler-Najjar syndrome type I. J Pediatr Gastroenterol Nutr 2008;46: 30811.

22 Bosma PJ, Chowdhury JR, Bakker C, Gantla S, de Boer A, Oostra BA, Lindhout D, Tytgat GN, Jansen PL, Oude Elferink RP, et al: The genetic basis of the reduced expression of bilirubin UDP-glucuronosyltransferase 1 in Gilbert's syndrome. N Engl J Med 1995;333: 1171-1175.

23 Lodoso Torrecilla B, Palomo Atance E, Camarena Grande C, Díaz Fernández MC, Hierro Llanillo L, De la Vega Bueno A, Frauca Remacha E, Muñoz Bartolo G, Jara Vega P: Crigler-Najjar syndrome: diagnosis and treatment. An Pediatr (Barc) 2006;65: 73-78.

24 Strauss KA, Robinson DL, Vreman HJ Puffenberger EG, Hart G, Morton DH: Management of hyperbilirubinemia and prevention of kernicterus in 20 patients with Crigler-Najjar disease. Eur J Pediatr 2006;165: 306-319.

25 Jansen PL: Diagnosis and management of Crigler-Najjar syndrome. Eur J Pediatr 1999; 158(suppl 2):S89-S94.

26 Nydegger A, Bednarz A, Hardikar W: Use of daytime phototherapy for Crigler-Najjar disease. J Paediatr Child Health 2005;41: 387-389.

27 Shimizu N, Mizutani M, Aoki T: A case of Crigler-Najjar syndrome type I: long survival with bilirubin adsorption and liver transplantation (in Japanese). No To Hattatsu 2005;37:337-341.

28 Coutelle C, Themis M, Waddington SN, Buckley SM, Gregory LG, Nivsarkar MS, David AL, Peebles D, Weisz B, Rodeck C: Gene therapy progress and prospects: fetal gene therapy-first proofs of concept - some adverse effects. Gene Ther 2005;12:1601-1607.

29 Toietta G, Mane VP, Norona WS, Finegold MJ, Ng P, McDonagh AF, Beaudet AL: Lifelong elimination of hyperbilirubinemia in the Gunn rat with a single injection of helper-dependent adenoviral vector. Proc Natl Acad Sci USA 2005;102:3930-3935.

30 Raimondi F, Capasso L, Migliaro F, Romano A, Paludetto R: Prenatal exposure to conjugated bilirubin. Pediatrics 2006;118:2265.

31 Bashore RA, Smith F, Schenker S: Placental transfer and disposition of bilirubin in the pregnant monkey. Am J Obstet Gynecol 1969;103:950-958.
32 Schenker S, Dawber NH, Schmid R: Bilirubin metabolism in the fetus. J Clin Invest 1964;43:32-39.

33 Waffarn F, Carlisle S, Pena I, Hodgman JE, Bonham D: Fetal exposure to maternal hyperbilirubinemia: neonatal course and outcome. Am J Dis Child 1982;136:416-417.

34 Serrano MA, Bayòn JE, Pascolo L, Tiribelli C, Ostrow JD, Gonzalez-Gallego J, Marin JJ: Evidence for carrier-mediated transport of unconjugated bilirubin across plasma membrane vesicles from human placental trophoblast. Placenta 2002;23:527-535.

\35 Pascolo L, Fernetti C, Garcia-Mediavilla MV, Ostrow JD, Tiribelli C: Mechanisms for the transport of unconjugated bilirubin in human trophoblastic BeWo cells. FEBS Lett 2001;495:94-99.

>36 Bittigau P, Sifringer M, Ikonomidou C: Antiepileptic drugs and apoptosis in the developing brain. Ann Y Acad Sci 2003;993:103114.

37 Perucca E: Birth defects after prenatal exposure to antiepileptic drugs. Lancet Neurol 2005;4:781-786.

38 Motamedi GK, Meador KJ: Antiepileptic drugs and neurodevelopment. Curr Neurol Neurosci Rep 2006;6:341-346.

39 Ornoy A: Neuroteratogens in man: an overview with special emphasis on the teratogenity of antiepileptic drugs in pregnancy. Reprod Toxicol 2006;22:214-226.

$\checkmark 40$ Kjaer D, Horvath-Puhò E, Christensen J, Vestergaard M, Czeizel AE, Sorensen HT, Olsen J: Use of phenytoin, phenobarbital, or diazepam during pregnancy and risk of congenital abnormalities: a case-time-control study. Pharmacoepidemiol Drug Saf 2007; 16:1818.

$>41$ Jones LL, Johnson KA, Chambers CC: Pregnancy outcome in women treated with phenobarbital monotherapy (abstract). Teratology 1992;45:452.

-42 van der Pol MC, Hadders-Algra M, Huisjes HJ, Touwen BC: Antiepileptic medication in pregnancy: late effects on the children's central nervous system development. Am J Obstet Gynecol 1991;164:121-128.

43 Shapiro S, Slone D, Hartz SC, Rosenberg L, Siskind V, Monson RR, Mitchell AA, Heinonen OP: Are hydantoins (phenytoins) human teratogens. J Pediatr 1977;90:673-675.

44 Oh W, Tyson JE, Fanaroff AA, Vohr BR, Perritt R, Stoll BJ, Ehrenkranz RA, Carlo WA, Shankaran S, Poole K, Wright LL: Association between peak serum bilirubin and neurodevelopmental outcomes in extremely low birth weight infants. Pediatrics 2003;112:773-779.

45 Cahshore WJ, Oh W: Unbound bilirubin and kernicterus in low-birth-weight infants. Pediatrics 1982;69:481-485.

46 Cashore WJ: The neurotoxicity of bilirubin. Clin Perinatol 1990;17:437-447.

47 Shapiro SM: Definition of the clinical spectrum of kernicterus and bilirubin-induced neurologic dysfunction (BIND). J Perinatol 2005;25:54-59. 